\title{
Factors influencing Agripreneurship and their role in Agripreneurship Performance among young Graduate Agripreneurs
}

\author{
Laud Kpakpo Addo
}

\author{
Email: laddo481@gmail.com
}

\begin{abstract}
Participation of young people in agriculture is not only needed towards addressing food security and youth unemployment challenges, but also critical in tackling issues of ageing farmers, technological and digital revolution in the agrifood sector, changing trends in food needs and consumption demands, and environmental changes and natural resource degradation. This paper argues for inclusive approach to involving youth in the expansive agrifood system, stressing the importance of young graduates (highly educated youth) participating in the agrifood sector, hence the need for steps to attract, support and retain them in the agrifood sector. Thus, this study sought to identify the factors that influence agripreneurship, and how these factors influence agripreneurship performance of young graduate agripreneurs. The study results and agripreneurship framework, emphasizes the need for a holistic (multilevel) examination and approach to agripreneurship; gender-sensitive, integrated and applied approach towards promoting and developing agripreneurship competencies among young graduates, which must include enhancing both enterprising traits and skills, and strong technical/professional business management competencies.
\end{abstract}

Keywords- Agriculture, Agrifood, Agripreneurship, Entrepreneurship, Graduate, Youth

\section{INTRODUCTION}

The global demographic dynamics and transition will have varying socio-economic effects on countries and the larger global community. Data from the UN DESA (United Nations Department of Economic and Social Affairs) suggests high population particularly for less developed regions of the world, with young people constituting a significant cohort. This raises a number of important issues including how to produce enough nutritious food to meet the expected increases in food needs, and how to find decent and sustainable jobs especially for the large youth population. These is sues are critical with respect to Africa because even though the continent is projected to experience high population, agricultural productivity on the continent remains very low and the economies are largely characterised by low levels of decent and sustainable jobs (ILO, 2017; Ehui and Pender, 2015). However, in seeking to address these issues, the agro-potential of many African countries and the continent's youth bulge becomes of strategic importance. As noted by Zorya, Gautam and Goyal, "agriculture is uniquely positioned to absorb these workers" [i.e. large cohort of young Africans] (2013, p. 2). Active youth engagement in agriculture (or more broadly the agrifood space), can contribute positively to addressing not only the issues of producing enough nutritious foods and providing decent jobs for young people, but can also have other positive outcomes: feeding and fuelling agro-processing industries, boosting the non-farm economy, and increasing national revenue generation via taxation and foreign exchange earnings among others. The multiple benefits and scales of impact that could be exacted from a synergistic relationship between youth and agriculture have ignited discourse on youth-in-agriculture in policy and development circles.

In seeking to engage more youth in agriculture, most interventions have seemingly focused on rural and/or less educated youth. However, considering the changes within the agrifood space, and the larger socio-economy, it is important for the youth-in-agriculture drive to be more inclusive. For instance in many African countries, graduate unemployment has become major development challenge and in Ghana, data shows that unemployment among young people in urban areas, who are relatively more educated, is higher $(6.5 \%)$ than those in rural areas (4.3\%) (see "Almost half of the 10 million graduates", 2016; GSS, 2014a). Furthermore, ongoing changes within and outside the agrifood space such as technological advancement, dynamics in food needs and demand, and environmental changes, is transforming how food is produced, sold and consumed. All of these make it imperative for participants in the modern agriculture and food industry to have high-end professional knowledge and skills. Thus, this paper argues that the drive to engage youth in agriculture must endeavour to attract, engage and 
retrain young graduates (highly educated youth) in the agrifood space. This argument falls in line with calls for youth heterogeneity (sex/gender, age and skills level, among others) to be recognised in the youth in agriculture agenda (Flink, I., Vaast, C., Jacobs, J. and Turolla, M, 2018; Goemans, 2014; Bennell, 2007).

Young graduates may either have the professional and/or technical training needed in the modern and evolving agrifood landscape (such as those trained in agriculture and/or food studies), or that their high-levels of education and exposure can be leveraged for them to acquire further or new competencies to enable them productively participate in the sector. As argued that agriculture needs to be modernised to attract young people, similarly in the present complex and evolving agrifood sector, and considering young graduates in particular, they cannot - whether out of their own ignorance or by design of external stakeholders participate in the agrifood space using the conventional approach (usually phrased as 'hoe and cutlass') and be successful (higher productivity and incomes). Young people, especially graduates, are expected more than ever to become more entrepreneurial and contribute actively towards addressing social and national development issues including their own thorny issue of graduate unemployment. This entrepreneurial demand of graduates cannot be more needed than in agrifood sector, a dynamic and challenging sector, yet one that holds much promise and prize for its adventurers and the larger society (see also Montpellier Panel, 2014).

In contributing to the youth in agriculture discourse and practice, this study focused on young graduate agripreneurship, and sought to identify the factors that influence agripreneurship and how these factors influence (facilitated or inhibited) agripreneurship performance among young graduate agripreneurs. The study makes instrumental input towards informing the development of young graduate agripreneurs. This study did not seek to measure the entrepreneurial performance of young graduate agripreneurs, which would have required using indicators such profitability, employment generated, revenues, sales or production volumes among others (see Zamanian, 2017).

The next section of this paper reviews study literature, followed by the study approach and methodology, after which the study findings and discussion are presented, and finally the conclusion and recommendations.

\section{LITERATURE REVIEW}

The global demographic changes and transitions will lead to among others a huge youth population (youth bulge) in Africa. Considering the continents relatively low levels of agricultural productivity and weak economies, the demographic changes raises critical concerns about food security and employment on the continent. Whiles being a challenge on its own, the youth bulge also presents an opportunity for addressing the concerns of food security and employment through enhanced youth participation in the agricultural sector. Youth participation in the agriculture sector can also contribute to addressing the changes occurring in the sector. This section of the paper discusses the foregoing issues providing a contextual appreciation for this study.

II.a Demographic Transitions, Youth and Agriculture The United Nations DESA (Department of Economic and Social Affairs), estimates world population to reach over 8.5 billion by 2030 and over 9.7 billion 2050 with a significant youthful cohort; those between the ages of 15 to 34 years will make up to 2.45 billion $(29 \%)$ and 2.64 billion $(31 \%)$ of the global population by 2030 and 2050 respectively (UN DESA, 2017). In Africa, those between the ages of 15 to 34 years will reach almost 580 and 830 million people by 2030 and 2050 respectively (accounting for 34 and 33 percent of the population in 2030 and 2050 respectively) (ibid). In Ghana, total population projections indicate it reaching over 36 and 50 million by 2030 and 2050 respectively, with those between 15 to 34 years constituting $34.7 \%$ in 2030 and $33 \%$ in (ibid). Currently of the estimated 26 million people in Ghana, 34.1\% are between 15 to 35 years, and of these, $18.2 \%$ and $15.9 \%$ are females and males respectively (GSS, 2014a). Ghana's definition of youth follows that of the Africa Union, which is those between the ages of $15-35$ years (Africa Union, 2006; Ministry of Youth and Sports, 2010). Food security is one of the major concerns associated with the projected population increase; how to provide adequate and nutritious food for the increasing population.

While it is thought that with increases in GDP and per capita income, world food production will rise to meet the increases in food demand, the situation for sub-Saharan Africa remains a worry (Alexandratos and Bruinsma, 2012). Though Africa will experience high population increase, it continues to face "inadequate food consumption and high levels of undernourishment"; by 2030 and 2050, 14.5 million and 7.1 million people respectively are still expected to remain undernourished in Africa (ibid, 2012, p. 2). In Ghana notable numbers of the population (about 5\% of the population) remain undernourished and/or in poverty, with inequality being prevalent - and even increasing - in some parts of the country (McKay, Hague and Cooke, 2016; FAO, 2015; NDPC and UN Ghana, 2015; GSS, 2014b). Additionally, Ghana spends substantial amounts on the importation of staple foods such as rice, sugar, tomatoes and poultry 
('Food Imports', 2018). The foregoing, amidst the trend of increasing global food prices, Ghana's weakening currency and periodic shocks to the agriculture sector (such as disease and/or pest attack, flooding, and drought), makes the country's food sufficiency and security vulnerable. Other countries in the region are in much worse situations due to added burden of conflict and disease (HIV/AIDS).

In seeking to address this challenge within the context of a socio-economy which is changing along with its agrifood sector, and the rather low levels of agricultural productivity on the continent, young people become crucial; their numbers, energies, curiosity and adaptability can be harnessed within the agriculture sector towards ensuring improved food security. In the pursuit of this agenda, rural youth and/or generally less educated youth, have been the key target of efforts to engage young people in agriculture; the reasons include seeking to address unemployment among rural and/or out-of school youth, leveraging 'abundant' rural natural resources for improved food security, stimulating rural economic growth and addressing rural poverty, (see Pyburn, AudetBélanger, Dido, Quiroga and Flink, 2015; Saginga, 2013; Filmer and Fox, 2014; UNIDO, 2013; Brooks, Zorya, Gautam and Goyal, 2013; Oppenheimer and Spicer, 2011). However, in order to meet the new and emerging changes, demands and trends within the agrifood sector and the larger socio-economy, the youth-in-agriculture drive must be made more inclusive attracting in particular highly educated and skilled youth (young graduates). This is echoed by Weidinger, Youdeowei, University of Greeenwich, Mwaura and Quaye, who posits that "young people, who are dynamic and better educated...should be considered prime candidates for the required cadre of human capital needed to move African agriculture forward" (2015, p. 66).

The agrifood sector is being altered in new ways and forms, demanding 'new' crop of participants in the sector. The production, transportation, processing, marketing and consumption of food is now more complex and still evolving even as consumer needs and demands change (increased demand for more refined foods [processed, more nutritious, better packaged, ready-to-eat/serve], fruits, vegetables, dairy food and meat) (see EIU-BCN, 2017; FAO, 2017). As in other sectors, technological and digital progress is revolutionizing the agrifood space agritech). De Clercq, Vats and Biel (2018), notes that the influence of agritech will be on three broad fronts; "1) produce differently using new techniques; 2) Use new technologies to bring food production to consumers, increasing efficiencies in the food chain; 3) Incorporate cross-industry technologies and applications" (p. 11). Conceivably, the sector most vulnerable to the ongoing environmental change is the agriculture sector. The consequences and ramifications of environmental and natural resource destruction and degradation on the agriculture sector and the many livelihoods that depend directly and indirectly - on the sector are grave. Thus, it is suffice to say that going forward, agrifood systems need daring, enterprising and better educated participants having requisite knowledge and skills, or are ready and capable of acquiring these knowledge and skills, and using them to build more sustainable and resilient agrifood systems (see also Montpellier Panel, 2014).

Fortunately, in this regard it is soothing to note that there is generally increasing levels of education attendance and attainment among young people in Ghana; since 2005, both gross and net school attendance at the senior secondary level has been increasing (see GSS, 2014b, p. 42). Gross enrollment in tertiary education is also increasing; in 2008 this stood at $8.63 \%$ compared with 16.6\% in 2017 (UNESCO, 2018). However, as may be expected, educational attainment (senior secondary level and higher) among urban youth is higher (32.6\%) than among rural youth (11.6\%) (see GSS, 2014a, p. 45); this further echoes the need for a more inclusive youth-inagriculture drive leveraging these diversities and educational attainments. In Ghana, and perhaps many other countries, young people are also needed to replace ageing farmers; for example the average age of cocoa farmers in Ghana is estimated at an advance age of 55 years (Fick, 2015). The participation of youth in agriculture is also vital to addressing the issue of youth unemployment (discussed in the following section). Thus, as Sumberg, Anyidoho, Leavy, te Lintelo and Wallard (2012) puts it, whether framed from the perspective of “'youth in peril' or 'agriculture in peril' " (p.3), agriculture provides a strategic opportunities for productively and sustainably engaging the growing numbers of young people, yielding different types and levels of benefits.

Though the general narrative is that young people shun agriculture (farming), other studies have highlighted issues of aspirations and constraints to engaging in agriculture as contributing to deter young people from agriculture (see Dyer, 2013; Anyidoho, Leavy and Asenso-Okyere, 2012). Thus, as opined by Anyidoho, Leavy and Asenso-Okyere (2012), a blanket assertion that "young people in SSA are choosing to reject agriculture wholesale" lacks sufficient proof (p. 2). Evidence from the interest and participation of young people, especially educated ones, in recent agriculture centered or related activities (competitions, events, networks and incubators) indicates continuing and perhaps growing interest of educated young people in the agriculture sector, and an emerging crop of young graduate entrepreneurs in the 
agrifood sector. Some of these programs include the African Youth Agripreneurship Program (AYAP), Enhancing Growth in New Enterprises (ENGINE), Kosmos AgriTech Challenge, ENABLIS Business Launchpad, Total StartUpper Competition, Youth Enterprise Support (YES), Empowering Novel AgriBusiness-Led Employment (ENABLE), Young Professionals for Agricultural Development (YPARD) and other recent agric-focused conferences in Ghana (Young People, Farming and Food Conference), Cote d'Ivoire (Youth Agripreneur Forum and AgriPitch Competition), Nigeria (Youth Entrepreneurship Summit for Agribusiness Advancement) and Rwanda (Youth Employment in Agriculture as a Solid Solution to ending Hunger and Poverty in Africa). These emerging young entrepreneurial 'farmers' could be motivated by personality (proclivity for an agrifood activity or livelihood) or necessity: push factors (unemployment or underemployment) or pull factors (identified or given opportunity) (see Schoof, 2006); within the Ghanaian context, necessity is said to drive most entrepreneurial activities (Herrington and Kelly, 2013).

II.b Youth Unemployment, Entrepreneurship and Agripreneiurship

Youth unemployment and underemployment are major global challenges particularly for developing countries, and other weak economies. According to the ILO (International Labour Organization), globally for every one unemployed adult, there are three unemployed youth (ILO, 2017). The ILO further reports that a total of 70.3 million young people (15-24 years) were unemployed in 2017, and this is will rise to 71.1 million in 2018 (13.1\%) (ibid). For developing countries, "the unemployment rate among youth [15 - 24 years] is expected to remain stable at $9.5 \%$ in 2017 and 2018. However, considering the large cohort of young people entering the labour force each year, the number of unemployed youth in developing countries is projected to increase by half a million between 2016 and 2018" (ibid, p. 15). In Africa, Northern Africa has high incidence of youth unemployment (28.8 $\%$ ), and a youth-to-adult unemployment rate ratio of around 3.5. For sub-Saharan Africa, youth unemployment was estimated at $11.1 \%$ in 2017 and projected to rise marginally to $11.2 \%$ in 2018 (ibid). However, it is important to note that, the figures exclude all unemployed people between the ages of 25 - 35 years, who also constitute youth on the continent (African Union, 2006). Regarding data on unemployment, cognisance must be taken of germane concerns about data deficiencies and gaps in many countries, Ghana included. This makes determination of levels of unemployment - general or among youth - difficult and/or inaccurate. In addition, the current definition of unemployment is noted to have some limitations, and does not allow capturing of all underutilized labour such as underemployed, discourage job-seekers and potential labour force (see BaffourAwuah, 2014; GSS, 2014a; Dewan and Peek, 2007); in Ghana, whiles the national youth unemployment is estimated at $5.5 \%$, youth labour force underutilization is more than seven times this figure, $42.6 \%$ (GSS, 2014a).

A critical aspect of youth unemployment is graduate unemployment, which has become an albatross around the neck of governments and a scar on the conscience of society which touts education as panacea to unemployment. In Ghana it is estimated that 250,000 educated youth join the labour force annually, of which $31 \%$ have some tertiary qualification $(77,500)$. Out of this, only $6.5 \%$ (5000) find formal employment with the rest having to join the informal sector or remain unemployed (Oben-Torkornooo, 2009). As educational levels increase with more young people attaining higher levels of secondary and post-secondary education, the trend will continue if enough job opportunities are not generated at a faster rate. Unemployed youth, especially having achieved higher levels of education, do not only suffer from psychological and social challenges such as depression and social exclusion (see Moreane, 2006), but also from food insecurity; they do not have enough money to buy and consume both the right quantity and quality of food (Feighery, Ingram, Li and Redding, 2011). In seeking to address the challenge of unemployment among the young people, entrepreneurship is one of the strategies often suggested and/or used, and is included in many youth-centered policies, plans and strategies (see Ministry of Employment and Labour Relations, 2014; UNDP, 2014; OECD, 2013; Ministry of Youth and Sports, 2010; Commonwealth Secretariat, 1998). Participation of young people in entrepreneurship programs enables them to among others acquire and/or enhance enterprising skills, knowledge, traits and competencies leading in many cases to youth-led ventures focused on various socio-economic challenges. Thus entrepreneurship has come to assume an important option for tackling diverse issues across different domains.

'Entrepreneurship' is said to come from the French word 'entreprendre', meaning 'to undertake' and reportedly was first used by Richard Canitillon, a French banker, with another Frenchman, Jean Batiste Say, popularizing the term (Ananga, 2015; Pahuja, 2015; Buame, 2009). They are different definitions of the term from different authors (see Braunerhjelm, 2010, pp. 910), however the views of Schumpeter and Kirzner are said to have gone on to influence many other entrepreneurship definitions (Ananga, 2015; Buame, 2009). Joseph Schumpeter defined entrepreneurship as, 
"an innovative process where an individual or group of individuals create something new: a new product (goods or services); a new market (hitherto unexploited); a new source of raw material; a new method of doing things" (Buame, 2009, p. 24). Whiles for Israel Kirzner, "entrepreneurs can be seen as responsible for equilibrating market movements (such as changing prices), in the absence of dramatic changes in product specifications or in production methods. My entrepreneurs were engaged in arbitrage, acting entrepreneurially even when they might not be seen as Schumpeterian "creators" " (Kirzner, 2008, p. 5). Other entrepreneurship definitions which feed into the 'entrepreneurs are born' face criticisms, with Peter Drucker stating that "everyone who can face up to decision making can learn to be an entrepreneur and to behave entrepreneurially. Entrepreneurship, then, is behaviour rather than personality trait" (1985, p. 26). Davidsson and other authors have argued and/or shown that entrepreneurship is a multilevel phenomenon; individual, firm and social levels; which aside being a process, has outcomes (see Martin and Osberg, 2007; Davidsson, 2005; van der Veen and Wakkee, 2004). It is thus not surprising that concept has found its way into other domains leading to new constructs such as 'intrapreneurship', 'infopreneurship', 'webprenenurship', social entrepreneurship and now agripreneurship.

Carr and Roulin (2016) give two definitions of Agripreneurship: first, "an entrepreneur whose main business is agriculture or agriculture-related" (p. 9), citing Dabson and Markley (2009); and the second being, "generally sustainable, community oriented, directly marketed agriculture. Sustainable agriculture denotes a holistic, systems oriented approach to farming that focuses on the interrelationships of social, economic and environmental process" (p. 9), citing Sudharani n.d. The second definition brings aspects of social entrepreneurship (see Bornstein and Davis, 2010; Öztürk, 2013) into agripreneurship and feeds into the ongoing global agenda of sustainable development of which the sustainable and resilient agriculture has been identified as being critical to achieving many of the SDGs (see FAO, 2018). From the foregoing definitions of agripreneurship, gleaning from the different definitions or explanations of entrepreneurship and with the appreciation of the xpansive agrifood space, this study posits the following definition of Agripreneurship:

Identifying and seizing an opportunity (problem, idea, business or market imbalances) in the agrifood space and organising resources to convert the opportunity into solutions (new or innovative produce, product or service) whiles embracing the associated risk and potential benefits thereof (material and immaterial); this may occur within an existing agrifood enterprise or lead to establishment of new agrifood enterprise.

As noted by McElwee (2015), (citing several authors), the business of farming is entrepreneurial in nature, thus the "the methods used to analyse business entrepreneurs in other sectors can be applied to (entrepreneurial) farmers" (p. 2). It has also been noted that the lack of adequate entrepreneurial skills by small business owners is an important challenge and cause of failure among small businesses (Ananga, 2015; Adjei, 2012). Thus, attempts and interventions aimed at supporting and enhancing the emergence and/or growth of small businesses including agrifood enterprises; referred to as supportive Interventions in this study; are vital in the process of entrepreneurship and for that matter agripreneurship. Such supportive interventions include business plan/pitch competitions, small business growth and acceleration programs and innovation hubs, and mentorships and financial support and literacy programs among others. Examining the broad scope of literature on entrepreneurship, including also within the agriculture context, factors that influence agripreneurship are identified. These factors are subsequently examined as to how they influence agripreneurs hip performance of young graduate agripreneurs. The next section outlines the research method and approach used.

\section{APPROACH AND METHODOLOGY}

A case study strategy involving mainly qualitative methods was adopted for this study, thus data collection was intensive, with both study methods and data sources being triangulated. In this study, a young graduate agripreneurs was defined as: anyone between the ages of 19 - 39 years, who is pursuing or has completed a postsecondary education or training in a tutorial or tertiary institution and is an owner or owner-manager of an agrifood enterprise which had existed for at least six months. The official age range in the definition of youth in Ghana, that is $15-35$ years, was modified as the study focused on persons who had completed their secondary level education; the usual completion age being 17/18 years. Young graduate agripreneurship can be described as a nascent phenomenon in Ghana's agrifood system, thus the numbers of young graduate agripreneurs (research population) are few and far between, both in the larger agrifood system and in specific agrifood value chains. Two broad groups of agripreneurship was constructed to guide respondents selection; 1) young graduate agripreneurship in traditional agrifood activity (production, processing or marketing of traditional food or cash crops and animals) and 2) young graduate 
agripreneurship in non-traditional agrifood activity (production, processing or marketing of non-traditional food crops and animals such as mushrooms, guinea fowl, and snails among others). Young graduate agripreneurship providing services (such as market food prices, tractor services, and agrifood business plan services) were excluded. Subjective and snowball sampling techniques were used to select primary respondents; in all 24 respondents participated in the research. Qualified respondents were selected to participate in the study irrespective of their geographical location, with deliberate efforts being made to find and include females.

Data for this study was through a fieldwork in the months of July and August 2017. The research methods included an in-depth desk review involving both academic and grey literature, interview with key informants from various agencies, interview with primary respondents, observation, and focus group discussions and activities. In-depth desk review was used to explore literature background, operationalize constructs and delineate factors that influence agripreneurship. Five key informant interviews were conducted and it was used to examine the topic from perspectives; government, policyimplementing agencies, academia, and development institutions (local and international). The primary respondents were interviewed using a semi-structured questionnaire (with embedded quantitative questions) and this examined how the identified agripreneurship factors influenced agripreneurship performance among young graduate agripreneurs; each interview lasted between 1.5 to 2.5 hours. Observation was used to understand the activities of the agrifood enterprises of primary respondents, in one case the researcher participated in the activities of the agrifood enterprise (participatory observation). The use of observation enabled the researcher to probe/clarify already given answers, validate previous answers, and for more information to be gathered. Two focus group discussions and ranking activities were conducted to further explore the research objective from a group (social) perspective. This involved mainly young women (three in all) and men (seven in all) owning, owning-managing or working in agrifood enterprises. A deductive approach was used in the data analysis and the collected data was analysed by way of content/thematic analysis. Microsoft Excel was used to organize quantitative data collected. Draft study report (including preliminary findings) was also presented at a stakeholders meeting at AAIN (African Agribusiness
Innovation Network) towards enhancing construct and data validity. The research findings and accompanying discussions follows next.

\section{RESULTS AND DISCUSSION}

Disaggregated data on gender, the type of employment and educational background of respondents provides for interesting insight into youth agripreneurship and this is discussed under the first subsection. The next sub-section shows the findings from the rigorous literature review regarding delineation of factors that influence agripreneurship, and this is followed with the findings and discussion of the how the factors (personal factor) influenced agripreneurship in this study.

In all 24 qualified young agripreneurs were identified and participated in the research; table 1 below shows disaggregated data of the respondents. Even with the deliberate sampling methods used, only two females were identified and participated in the study. This contrasts data from the larger entrepreneurial field in Ghana, which has a slightly higher female entrepreneurship rate (38\%) than among men (35\%) (Herrington and Kelly, 2013). Albeit, in the agricultural sector, there are more male than female participants, with only a slight difference; $45.1 \%$ for males and $38.3 \%$ for females (GSS, 2014a). The huge difference or perhaps the difficulty in finding female young graduate agripreneurs in this study could indicate a less preference among young graduate females for the agrifood sector or perhaps there are constraints that hinder their participation. Opinions among respondents on the role/influence of gender (female or male) in the pursuit of agripreneurship were divided; some believed the drudgery of agriculture activities made the sector more suitable for males, whiles others differed and opined that females could actually partake in the sector.

Of the 24 respondents, eight $(33.3 \%)$ worked on a part-time basis, and had another job (source of income) which complemented benefits (income/food) gained from their enterprises. This supports the calls for issues of underemployment and low income to be critically examined in the youth employment discourse (see ILO, 2017; FAO; 2014, Bennell, 2007). Data also shows that majority of the young agripreneurs (21 [87.5\%]) are university graduates, out of which only five had undertaken agriculture or food related studies. This may very well indicate the possibility of youth of different educational backgrounds being able to actively participate in youth agripreneurship and how accommodating and engaging the sub-sector is or can be. 
Table.1: Disaggregated research data

\begin{tabular}{llc}
\hline \multicolumn{1}{c}{ Category } & Number of & Respondents \\
\hline Gender & Male & 2 \\
& Female & 22 \\
Part-time or Full-time & Part-time & 8 \\
& Full-time & 16 \\
Type of Post-Secondary School/Education & Tutorial College & 1 \\
& Polytechnic & 2 \\
& University & 21 \\
\hline \multicolumn{2}{c}{ Area (Subject) } & of Studies \\
Agriculture/Food Studies & & Number of Respondents \\
Business Studies (Finance, Marketing, Accounting, Commerce, Management) & 5 \\
Environment \& Natural Resource Studies & & 6 \\
Engineering Studies & & 2 \\
Political Science and Land Economy Studies & 2 \\
Design and Theatre Arts Studies & 3 \\
Science and Mathematics Studies & & 2 \\
\hline
\end{tabular}

Source: Research Data

IV.a Factors influencing Agripreneurship

A rigorous desk study was undertaken to identify the factors that influence agripreneurship; academic literature (published and unpublished), and grey literature, which also contained vast information, were scrutinized. During the process key entrepreneurship models and/or literature, many of which had also reviewed various other entrepreneurship models and literature, were identified and these provided critical information. Following the understanding of entrepreneurship being a process and outcome, with multilevel aspects, factors identified as influencing agripreneurship were put in three broad categories, namely Personal Factor, Organisational Factor and External Environment or Institutional Factor (see table 2 on the next page). The categorisation is encompassing, allows for further operationalisation and underscores a holistic (multilevel) approach to agripreneurship. Personal Factor refers to elements related to the person of the entrepreneur, such as psychology, trait, qualities, and experience among others. This category is akin to Individual Entrepreneurial Orientation (IEO), which many studies have confirmed is related to and/or influences business performance (see Koe, 2016). Entrepreneurial elements which are hinged upon the enterprise or should exist within the enterprise are grouped under Organisational Factor, whiles those existing outside of the entrepreneur and enterprise are grouped under External Environment or Institutional Factor.

Further literature reviews was undertaken towards operationalis ation of the three factor groupings, leading to delimitation of sub-dimensions and selection of indicators for the study. Following Botha, Veeruen and Kunne (2012), two sub-dimensions of the Personal Factor were constructed; Entrepreneurial and Personal Skills (EPS) and General Business and Technical Skills (GBTS). Applying the 'Black Box' of the IOM (Integrated Organisation Model) (see Lewinsky and Muharemovic, 2011) six sub-dimensions of the Organisational Factor was outlined; Organisational Structure, Staff/Team Members, Systems and Processes, Strategy, Culture and Management Style/Approach. Applying the PEST/ PESTEC tool four sub-dimensions of the External Environment/Institutional Factor was outlined: P (Laws, Policies and Programs and Political Dynamics); E (Economic \& Environment); S (Socio-Cultural) and $\mathrm{T}$ (Technology). These informed the agripreneurship performance conceptual framework of the study (fig. 1 on the next page). The three factor groupings are the independent variables that influence agripreneurship performance (dependent variable) with supportive interventions moderating this performance in terms of seeking to enhance or strengthen agripreneurship performance. As explained by O'leary (2004), dependent variable are the, "the things you are trying to study" and an independent variable is "what might be causing an effect on the things you are trying to understand" (p. 188). It must be noted that the term independent does not mean there are no influences on those variables themselves only that within the constraints of the research, those other possible influencing factors will not be studied (Verschuren and Doorewaard, 2010). 
Table.2: Categorisation fo the factors that influence entrepreneurship

\begin{tabular}{|c|c|c|c|}
\hline \multirow{2}{*}{$\begin{array}{l}\text { Entrepreneurship } \\
\text { Models or Literature } \\
\text { Works }\end{array}$} & \multicolumn{3}{|c|}{ Categories of Entrepreneurial Performance Factors } \\
\hline & Personal Factor & Organisational Factor & External En vi ronment or Institutional Factor \\
\hline Timmons Model & $\begin{array}{l}\text { Founders having right skills and } \\
\text { knowledge; Ambiguity; Creativity; } \\
\text { Communication Skills }\end{array}$ & Team; Business Plan & Opportunity; Resources; Exogenous Forces \\
\hline \multicolumn{4}{|l|}{$\begin{array}{l}\text { Source: Poerwowidagdo } \\
\text { and Wee Y. G (n.d.) }\end{array}$} \\
\hline Per Davidsson Model & Individual Factors & Idea (Business Idea) & Environmental Factors \\
\hline \multicolumn{4}{|l|}{ Sou rce: Davidsson, 2005} \\
\hline $\begin{array}{l}\text { Ahmad and Hoffman } \\
\text { (OECD) }\end{array}$ & Entrepreneurial Capabilities & $\begin{array}{l}\text { Research and Development; } \\
\text { Technology }\end{array}$ & $\begin{array}{l}\text { Technology Regulatory Framework; Access to } \\
\text { Finance; Market Conditions }\end{array}$ \\
\hline \multicolumn{4}{|l|}{$\begin{array}{l}\text { Source: Ahmadand } \\
\text { Hoffman, } 2007\end{array}$} \\
\hline $\begin{array}{l}\text { Bygrave Model (based } \\
\text { on Moore's Model) }\end{array}$ & Achievement; Locus of control & $\begin{array}{l}\text { Team; Strategy; Culture; } \\
\text { Products }\end{array}$ & $\begin{array}{l}\text { Competitors; Customers; Bankers; Suppliers; } \\
\text { Invest ors; Lawyers }\end{array}$ \\
\hline $\begin{array}{l}\text { Source: Nassif, Ghobril } \\
\text { \& da Silva2010 }\end{array}$ & $\begin{array}{l}\text { Ambiguity; Tolerance; Risk taking; } \\
\text { Personal values; Job } \\
\text { Satisfaction/Loses; Age; Vision; } \\
\text { Education; Experience; } \\
\text { Commitment; }\end{array}$ & & $\begin{array}{l}\text { Resources; Government policy; Incubator; Role } \\
\text { Models; Opportunities; Creativity }\end{array}$ \\
\hline $\begin{array}{l}\text { Hisrich and Peter's } \\
\text { Model }\end{array}$ & $\begin{array}{l}\text { Risk taking; Locus of control; } \\
\text { Personal values; Education; } \\
\text { Experience; Age; Job loss; Job } \\
\text { Dissatisfaction; Commitment; } \\
\text { Entrepreneur; Leader; Manager }\end{array}$ & $\begin{array}{l}\text { Team; Structure; Strategy; } \\
\text { Culture } \\
\text { Products }\end{array}$ & $\begin{array}{l}\text { Opportunities; Role Model; Competition; } \\
\text { Resources; Parents Incubat or; Customers; } \\
\text { Suppliers; Investors; Bankers; Lawyers; } \\
\text { Resources; Networks; Family; Government } \\
\text { Policy; Role Models }\end{array}$ \\
\hline Source: Kunene, 2008 & & & \\
\hline
\end{tabular}

Source: Author's compilation - sources indicated

Fig.1: agripreneurship performance framework

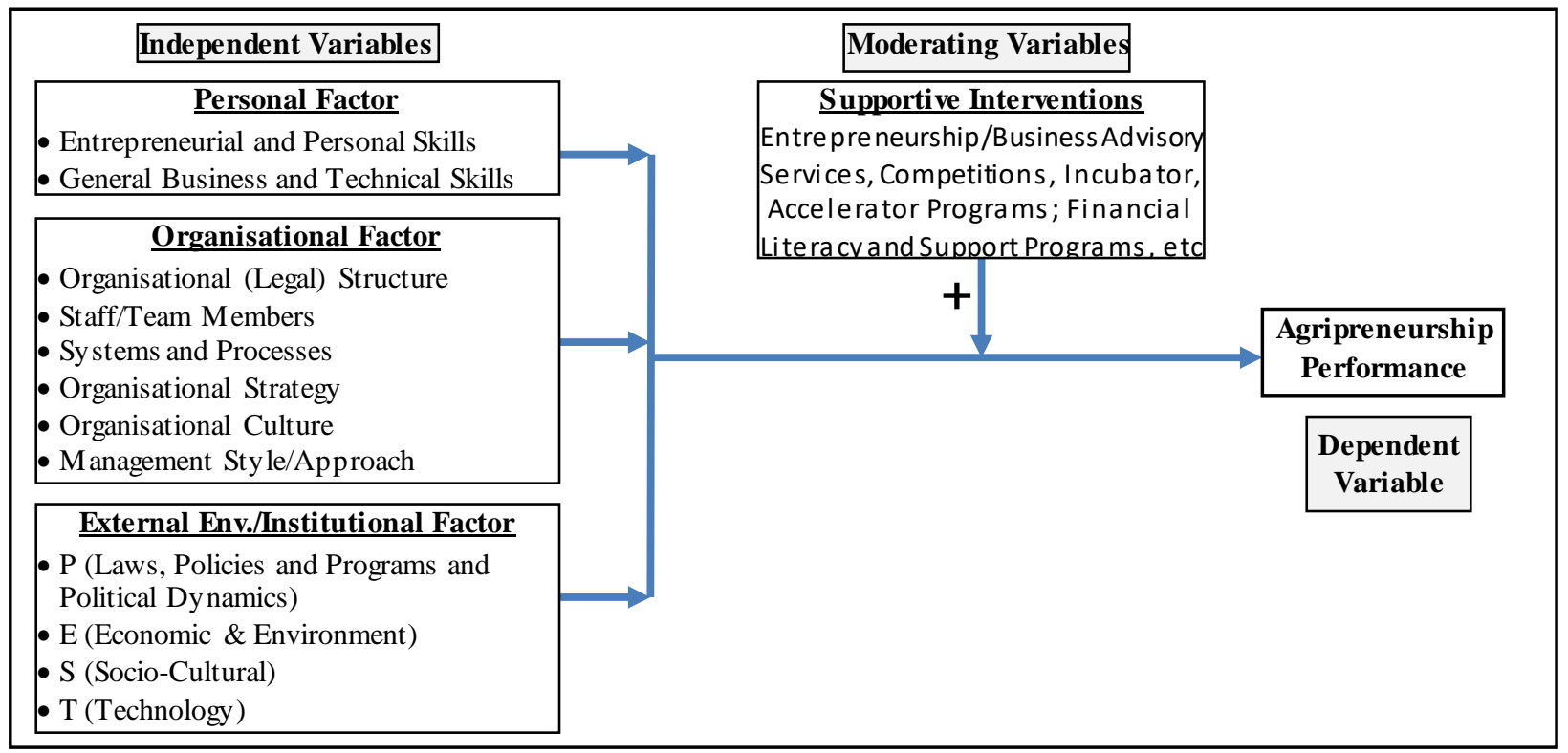

Source: Author's construct 
This paper focuses on the Personal Factor, subsequent papers shall focus on the on the other two groups of independent variables. Scanning various literatures showed a host of elements (indicators) centered on the Personal Factor (see table 3 below). Thus, a critical examination was carried out to select an encompassing and workable number of indicators fit for this study. After further interrogation of literature including the meaning (applied, contextual and general) of the various indicators, 14 key indicators (seven under each subdimension) were selected or framed for the study (see table 4 below). Using the semi-structured questionnaire, the 14 indicators were examined as to how they influence agripreneurship performance of respondents.

Table 3: List of various elements (indicators) of personal factor

\begin{abstract}
Initiative and drive; Innovative thinking; High sense of achievement; Sets example for himself; Hard work; Capacity to take risk; High intelligence and deep knowledge of the project or new venture; Long range vision; Motivation; Sound judgment; Leadership qualities; Taking full personal responsibilities; High level of ambition; Organizer of resources; Target setting and fighting for achievements; Sociable and flexible in his approach; Continuous learning by feedback; Future orientation.

Source: Saxena, 2013.

Individual smartness/ability to recognize highly potential business opportunity; Creativity; Innovativeness; Self efficacy /Self Confidence/Self-belief; Dedication \& Hard-work; Internal locus of control/believing that actions determine the rewards; Risk taking propensity/Attitude towards risk/taking calculated Risk ; Tolerance of Uncertainty/ambiguity; Sincerity and Commitment; Endurance/Continuing for long time; Good planning; Ability to make decisions; Flexibility / Adaptive to change; Goal oriented Source: Ratvi, 2013.

Motivation; Risk Tolerance; Vision; Mental ability \& Creativity; Clear Objectives; Good Communication Skills; Human Skills Source: Pahuja, 2015

Ability to Plan; Communication Skills; Marketing Skills; Interpersonal Skills; Basic Management Skills; Leadership Skills.

Pahuja 2015, citing University of Illinois Center for Economic and Financial Education

Confidence; Foresight; Perseverance, Determination; Accuracy-thoroughness; Energy, diligence; Cooperativeness; Responsibility;

Resourcefulness; Profit Orientation; Ability to take calculated Risks; Ability to learn from mistakes; Dy namism, Leadership M istakes;

Sense of Power; Optimism; Pleasant Personality; Need to Achieve; Egotism; Versatility, Knowledge of Product; Courage; Creativity; Imagination; Ability to Influence others; Perceptiveness; Ability to get along well with people; Toleration for Ambiguit y; Initiative; Aggressiveness; Flexibility; Capacity for Enjoyment; Intelligence; Efficacy; Orientation to clear Goals; Commitment; Positive Response to Challenges; Ability to trust Workers; Independence; Sensitivity to others; Responsiveness to suggestions; Honesty, Integrity; Time competence, Efficiency; Maturity, Balance; Ability to make decisions quickly.

Source: Amiri and Marimaei (2012)
\end{abstract}

Source: Author's compilation - sources indicated

Table.4: List of indicators of personal factors examined in this study

\begin{tabular}{|c|c|}
\hline Entrepreneurial and Personal Skills & General Business and Technical Skills \\
\hline 1. Creativity/Innovation & 1. General Business Management and/or Administrative Skills \\
\hline 2. Risk-taking or tolerance & 2. Business planning and/or Business Goal-Setting Skills \\
\hline 3. Initiative and Drive (Proactive) & 3. Communication Skills \\
\hline $\begin{array}{l}\text { 4. Determination and commitment (Persistent } \\
\text { and Dedicated) }\end{array}$ & 4. Team Building and Leading Skills \\
\hline $\begin{array}{l}\text { 5. Personal Effectiveness (Planning and time- } \\
\text { management) }\end{array}$ & 5. Financial Management Skills \\
\hline 6. Motivated to Succeed & 6. Marketing/Selling Skills \\
\hline 7. Self-confident and Shameless & $\begin{array}{l}\text { 7. Skills related to undertaking/working in the enterprise (technical } \\
\text { knowledge and/or skills) }\end{array}$ \\
\hline
\end{tabular}

Source: Author's compilation

The selected indicators capture entrepreneurial qualities suggested in other studies: the three domains of entrepreneurial qualities suggested by Kahan, (2013); the six domains of entrepreneurial competencies (see Lans, Bergevoet, Mulder and Van Woerkum, 2005 citing Man et al, 2002); the five domains entrepreneurial skills (see de Wolf and Schoorlemmer, 2007). The semi-structured questionnaire also made room for respondents to suggest other indicators outside the selected 14 which they deem important. The next section contains findings and discussions from the field. 
IV.b Influence of Personal Factor (EPS and GBTS) on Agripreneurship Performance

Among the three factorial groupings delineated, personal factor was rated as most important by all the individual respondents and also during the focus group discussion and exercises; figures 2 and 3 shows the scoring of the factor groupings by individual respondents and also during the two focus group discussions. This agrees with most literature which put the individual entrepreneur and her or his set of skills as being pivotal to the whole entrepreneurial process and its outcomes. Poerwowidagdo and Ghee (2011) reports Timmons as opining that "if the entrepreneur is equipped with the right skills and knowledge, he will be able to pull the right people

\section{Figure 2: Scores of the three factors by respondents}

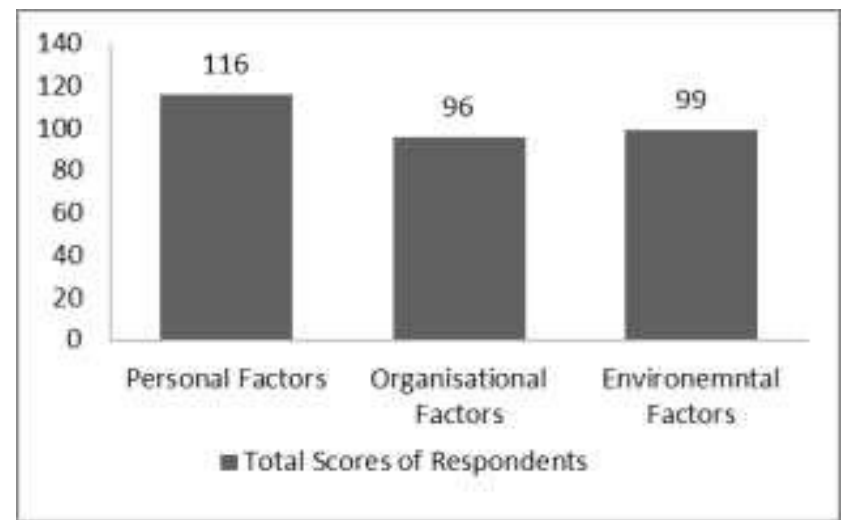

Source: Research Data together, search for relevant and ample resources to tackle the opportunity he sees in the market, shapes it well and turns it into potential business venture" (p. 3). Thus, the entrepreneurial qualities of the entrepreneur are decisive in the process of building an enterprise to leverage opportunities. Respondents scored/rated each of the seven indicators of the two sub-dimensions, after which further probing on each element (indicator) was carried out to unravel and understand how these elements influenced (facilitated/supported or inhibited/constrained) their agripreneurship performance; concrete context/situations and examples were asked to for meaningful appreciation of the influence of these elements. The findings and discussions flows in the next segments.

\section{Figure 3: Scores of the three factors by focus groups}

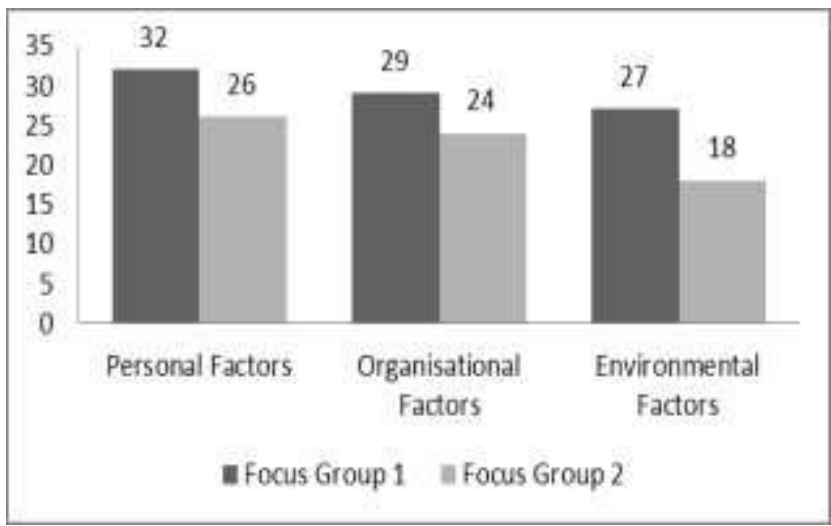

Source: Research Data
IV.b.1 Entrepreneurial and Personal Skills (EPS)

As evident from the graph (fig. 4 - next page), aside Personal Effectiveness, all other indicators were scored as being Sufficient and above, a clear indication of how strong agripreneurs deemed their EPS levels. The influence of the EPS could be summed up as including, 1) inspiration and decision to embark on the agripreneurship and working to maintain their agrifood enterprises; 2) learning, discovery and innovation and 3) developing a thick-skin (positively) and emotional strength. Kahan (2013) notes that starting and sustaining a new farm enterprise is an indication of some entrepreneurial qualities and also that emotional transformation (growth/maturity) - on the part of the agripreneur - is also needed as the business also goes through transformation. Respondents indicated having had to take difficult and uncomfortable decisions in pursuing their agrifood ventures; some had to forego their regular jobs its regular salaries, some respondents indicated having had to invest their life savings to start their enterprises hoping for a positive outcome, while others had to make their spouses quit regular employment to join them in their agrifood enterprises. Being motivated and determined to succeed they had to endure and continue their operations despite challenges such as mass crop failure and death of livestock, and low sales among others. All of the respondents have had to embark on a process of learning and discovery to either acquire or update their technical know-how, or to institute some innovation in their enterprises towards ensuring better operations, management and outputs. Both simple and sophisticated innovations such as a locally made carbonator and improved oil milling machines were observed. Whiles some respondents had produce entirely new products, others had also made adjustments such as better packaging and/or targeting and satisfying a niche market. This aligns with arguments that entrepreneurship can be about newness or not necessarily so (see Davidsson, 2005; Braunerhjelm, 2010 referencing Aldrich and Martinez, 2001). 
In addition to taking and facing risks, and dealing with sometimes difficult stakeholders (customers, suppliers), many respondents also had to face harsh criticis $m$ from family, friends or their community for being graduates yet engaged in farming; other studies have also reported farmer parents' hoping and acting for their children to pursue other livelihoods rather than farming (Leavy and Hossain, 2014; Anyidoho, Leavy and Asenso-Okyere 2012). These challenges had gone on to make respondents become thick-skinned (positively) and emotionally strong. The generally strong EPS, especially the determination and motivation to succeed, also reflect findings of the Global Entrepreneurship Monitor (2012), which noted a relatively lower business discontinuation rate $(16 \%)$ among entrepreneurs in Ghana, compared to some other African countries (Malawi-29\%; Angola26\%; Uganda-26\%; Zambia-20\%) (Herrington and Kelly,
2012). However, respondents were also candid about the weak aspects of these elements and how it influences (inhibits) their performance. For example respondents who deemed their personal effectiveness to be weak noted that effectively combining their personal lives and that of the enterprise was a challenge, and this inhibited their ability to make quick and effective decisions and/or implement decisions taken. During the study, respondents also mentioned Resource Mobilisation and Long-term Vision as being important enterprising and personal skills; these qualities are captured in entrepreneurship literature in same words or in antonyms such as resourcefulness and foresight (see table 3 above). Generally, the EPS was scored very high, was skewed in the positive direction with the skills generally mutually reinforcing.

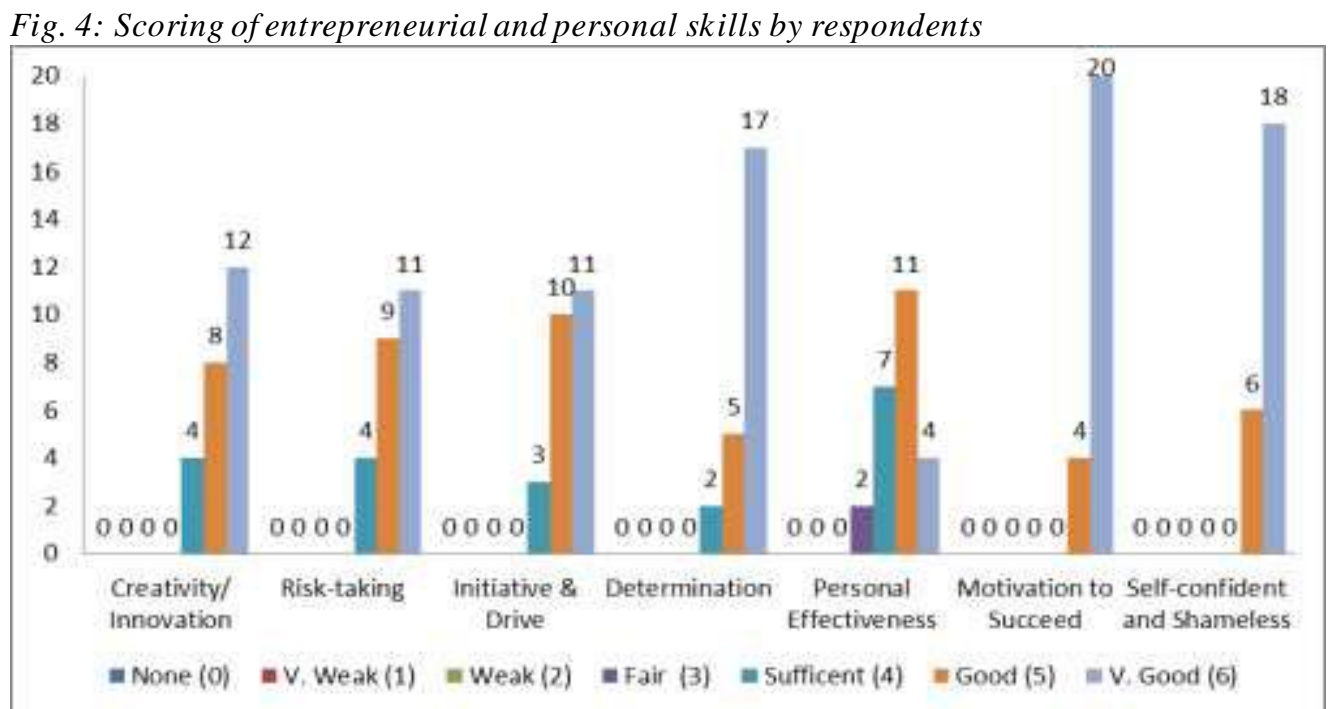

Source: Research

IV.b.2 General Business and Technical Skills

Like its counterpart, the GBTS had varying and reinforcing influence on the agripreneurs and their activities. These influences is summed up as including 1) planning and coordinating enterprise activities 2) administrative and technical management of daily activities and 3) building and maintaining relationships among internal and with external stakeholders (customers, suppliers, partners). Kahan (2013) opine that entrepreneurial personal qualities are not enough for the entrepreneurial farmer, they also "require knowledge in key areas of farm management: planning, implementing and controlling" (p. 52), and also that "their success can rest in the hands of other people. So they recognise the need to work with other people" (p. 57). During the study it was noted that, some of the processes and activities in the enterprise of agripreneurs were simple others were also quite complicated and advance, albeit the full attention of agripreneurs was demanded and respondents had to plan well, ensure proper coordination and to undertake the right activity at the right time, produce desirable produce/products, meet customers demand and/or supply at the right time. Whiles general administrative duties and planning was executed well, also indicated by high scores of related indicators (see fig. 5), administrative duties requiring technical or professional skills, particularly financial and marketing, was a challenge for some of the respondents. It was thus not surprising that respondents admitted market access being a challenge; many literature have identified this particular challenge as a critical factor for young people in agriculture and entrepreneurship (Brooks, Zorya, Gautam and Goyal, 2013; Adjei, 2012). Another respondent in admitting his weak financial skills, said that "I don't keep very good records; I just put everything in the business. If you ask me how much the business is now 
[business worth/value], I cannot really tell you" (Respondent, A). Respondents had to deal with various internal and external relationships towards ensuring sustained enterprise performance, meeting product standards, guaranteed market access and meeting customer demands. One respondent indicated that, his task even extended to settling dispute among farmers who formed part of his agrifood enterprise value chain. These were possible due to communication and team building skills much of which they acquired on the job.

Fig.5: Scoring of entrepreneurial and personal skills by respondents

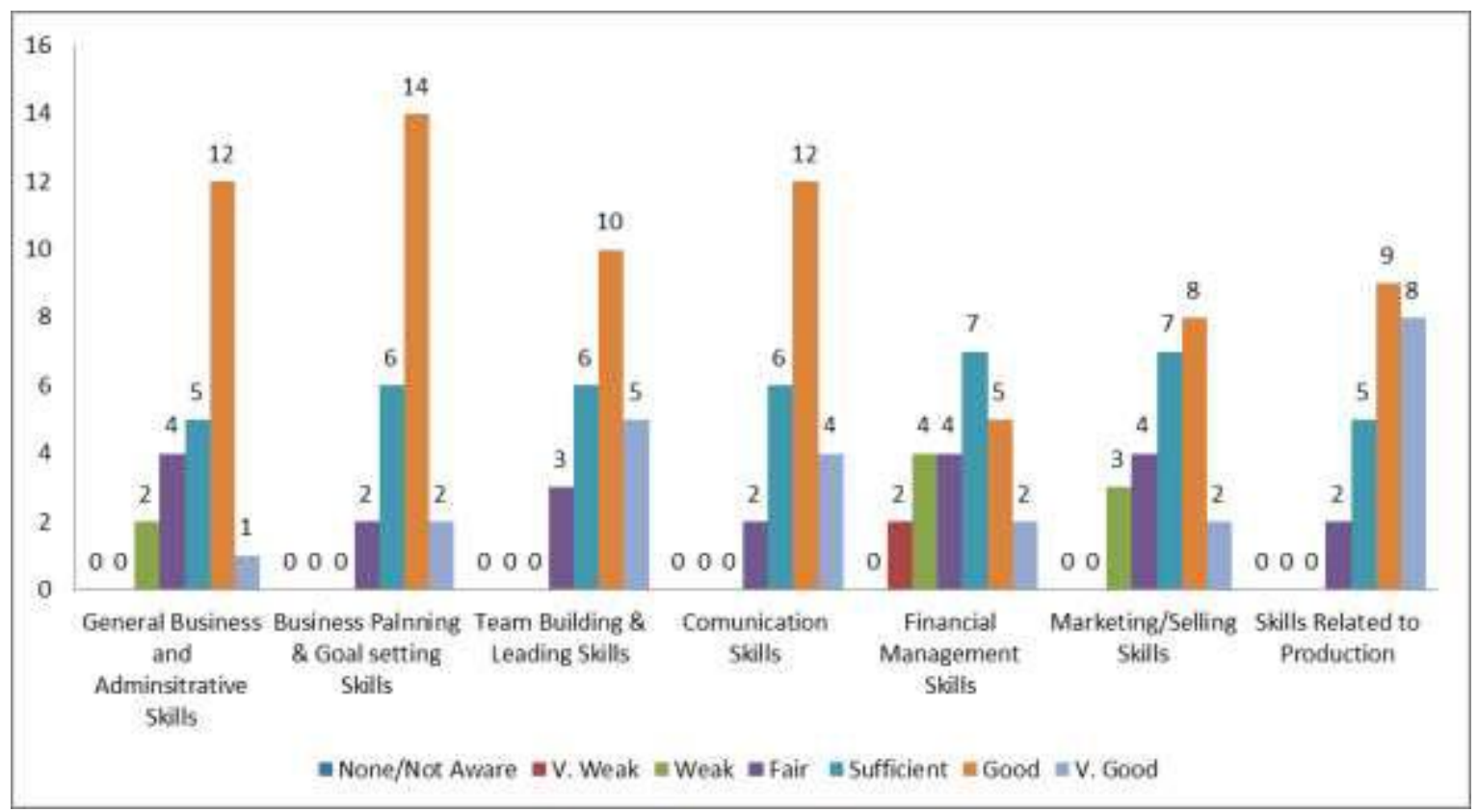

Source: Research Data

Comparing the EPS scores with that of the GBTS (figs. 4 and 5), the GBTS scores are very high, and also EPS scores were more spread out; whiles only one indicator of the EPS recorded a 'fair' score, each of seven GBTS had a 'fair' rating and some even lower. Among the two subdimensions, the GBTS can be said to be weaker than the EPS. This is unfortunate considering that successful business management of agrifood enterprises is important for ensuring higher profitability and good incomes, an issue which is noted to be a major concern for young people regarding taking up agriculture as a livelihood (see Leavey and Hossain, 2014). Proper business management in entrepreneurship ventures is also decisive for the growth and transition of nascent enterprises (Kahan, 2013). However, the low GBTS scores fit other findings which noted that EPS was deemed more important than GBTS (see Botha, van Vuuren and Kunene, 2015). In this study, it was observed that respondents with business related education had a more 2062rganized (and seemingly profitable) agrifood enterprise. This study aligns with authors and other findings which stress the importance of business management competencies/skills as being essential to 'holistic entrepreneurship', with Phelan stating that, "both an entrepreneurial and managerial skill-set are required to run a successful venture" (2014, p. 85). Thus, though the scoring was subjective, the results align with other arguments and findings.

\section{CONCLUSION}

Towards addressing the key issues of food security and unemployment amidst ongoing demographic transition, whiles also addressing important dynamics in the agrifood sector (ageing farmers, technological and digital revolution, emergence of an expansive and complex agrifood system and environmental changes), entrepreneurial participation of young graduates (highly educated youth) in the agrifood sector is of strategic importance and value. Thus the study focused on identifying the factors that influence young graduate agripreneurship and how these factors influence their agripreneurship performance with a view of contributing to how young graduate agripreneurship can be enhanced. The study showed that young graduates, irrespective of educational background, can actively participate in the agrifood space, more so since the production, supply and consumption of food has and continues to change/evolve. These changes incorporate different processes into agrifood systems and it allows different actors of diverse educational backgrounds to also participate in different 
areas (chains) of the system. Particular difficulty in finding sizeable female young graduate agripreneurs may well indicate the need for deliberate efforts at ensuring gender-inclusiveness in the nascent young graduate agripreneurship phenomenon. Three broad categories of factors (dimensions) can be said to influence agripreneurship; Personal, Organisational and External; with the Personal Factor dimension being pivotal. This categorisation is derived from diverse entrepreneurial models and literature, and provides an encompassing categorisation framework. The framework underlines a holistic perspective and approach to the examination of agripreneurship. Personal Factor was found to have varying influence on agripreneurship performance and cuts across the following sectional areas/topics of: 1) inspiration and decision to embark on the agripreneurship and working to maintain their agrifood enterprises; 2) learning, discovery and innovation and 3) developing a thick-skin (positively) and emotional strength; 4) planning and coordinating enterprise activities 5) administrative and technical management of daily activities and 6) building and maintaining relationships among internal and with external stakeholders (customers, suppliers, partners). These influences were noted to reinforce each other towards enhancing overall agripreneurship performance. Though it plays an important role in the stability, growth and transition of nascent and micro enterprises, technical/professional business competencies/skills were generally weak and this negatively affected sound business management of agrifood enterprises. In seeking to train and developed effective and efficient young graduate agripreneurs, it is important for the use of an integrated and applied approach which ensures acquisition and/or enhancement of the various elements of the Personal Factor (i.e EPS and GBTS). Technical business management competencies are as important as personal entrepreneurial competencies, and in training and developing young graduate agripreneurs, these skills must be an integral part of the training regime, more so, when it is desired for micro entrepreneurial ventures to grow and transition into small and medium scale enterprises for greater socioeconomic impact.

Like all research activities, this study had some limitations. The use of a case study approach implies that the findings of this research though provide detailed insights, data may not be applicable to the broader population, more especially when the young graduate agripreneurship is still budding; this informed a rigorous triangulation of method and sources, and the use of a relative sizeable number of respondents. Use of purposive sampling and snowball sampling is noted to having some influence on findings such as biasness and similar responses from respondents. Towards eliminating or at least reducing this effect, each interview was conducted on a one-on-one basis without the presence of other respondents. Additionally, in cases where a respondent had provided a lead to another potential respondent, the researcher took control in establishing contact with the potential respondent. Subjective data and scores are vulnerable to either exaggeration or deprecation. It was therefore important to seek concrete examples from respondents and also to situate and compare the findings of this research within other tested arguments and empirical studies. In some cases (very limited) quotations of respondents had to be 'cleaned' to fit the format and/or formality of this report; however this is deemed insufficient to invalidate research findings. Mention must be made of the numerous elements under Personal Factor, though the study focused on a critical few.

Going forward other studies exploring other indicators under Personal Factor will contribute to understanding of this topic. Additionally, quantitative mechanisms and studies able to measure the strength of indicators under Personal Factor will also be helpful to this topic and the larger discourse of youth entrepreneurship. This study also makes it evidential the need for a gender-based study into young graduate agripreneurship, including how to promote young female graduate agripreneurs. Studies on young graduate agripreneurship along specific agrifood value chain - even as the chains evolve and develop may be needed in the long-run to generate valuable data for the development of those chains.

\section{ACKNOWLEDGEMENTS}

The author wishes to state that this research article is based on his thesis research during his studies at Van Hall Larenstein University of Applied Sciences, Netherlands. Whiles the author declares no conflict of interest in undertaking this research, he wishes to fully acknowledge and appreciate the Netherlands Fellowship Programme, thesis supervisor(s), key informants, respondents, and all other persons and organisations that supported his master's studies and/or this research in diverse ways.

\section{REFERENCES}

[1] Adjei, D. S. (2012). Micro, Small and Medium Scale Enterprises in Ghana: Challenges and Prospects. A Case Study of Sekondi-Takoradi Metropolis. (Master's thesis). Retrieved from https ://bit.ly/2F7kKE1

[2] African Union, (2006). African Youth Charter. Retrieved from https://bit.ly/2A5yOJJ

[3] Almost half of the 10 million graduates churned out of the over 668 universities in Africa yearly do not get job, Kelvin Balogun - President of Coca-Cola, 
Central, East and West Africa - has said, 2016. ACET for Africa. Retrieved from https://bit.ly/2yRig6m on 1 November 2018.

[4] Ehui, S and Pender, J. (2005). Resource degradation, low agricultural productivity, and poverty in subSaharan Africa: pathways out of the spiral. The Journal of the International Association of Agricultural Economists. doi.org/10.1111/j.01695150.2004.00026.X

[5] Ahmad, N. \& Hoffman, A. (2007). Framework for Measuring Entrepreneurship. Retrieved from https://bit.ly/2yRqwE9

[6] Alexandratos, N. \& Bruinsma, J. (2012). World Agriculture Towards 2030/2050: The 2012 Revision (ESA Working Paper No. 12-03). Retrieved from FAO website: https://bit.ly/1llkiWx

[7] Amiri, S. N. and Marimaei, R. M. (2012). Concept of Entrepreneurship and Entrepreneurs Traits and Characteristics. Scholarly Journal of Business Administration. $\quad$ Retrieved from https://bit.ly/2D6R1II

[8] Ananga, A. B. (2015). Entrepreneurial Orientation and SME Growth: A Study Of The Food Processing Sector Of Ghana (Master's Thesis). Retrieved from https://bit.ly/2qBTTWB

[9] Anyidoho, N. K., Leavy, J., \& Asenso-Okyere, K. (2012). Young people's aspirations in Agriculture; A case study of Ghana's Cocoa sector. Paper presented at International Conference on the Future of the Agrifood Sector. Retrieved from https://bit.ly/2qx6F8I

[10] Bennell, P. (2007). Promoting livelihood opportunities for rural youth. Retrieved from https://bit.ly/2qhUtbv

[11] Botha, M., Vuuren, V. J., \& Kunne, T. (2012). An Integrated Entrepreneurial Performance Model Focusing on the Importance and Proficiency of Competencies for Start-Up and Established SMEs. South African Journal of Business Management, 46 (3), pp. 55-65. doi: 10.4102/sajbm.v 46i3.101

[12] Braunerhjelm. P. (2010). Entrepreneurship, Innovation and Economic Growth. (SEF Working Paper 2010:02). Retrieved from Swedish Entrepreneurship Forum website: https://bit.ly/2CWhtEx

[13] Brooks. K., Zorya. S., Gautam. A \& Goyal. A. (2013). Agriculture as a Sector of Opportunity for Young People in Africa. (Policy Research Working Paper 6473). Retrieved from World Bank Open Knowledge Repository website: https://bit.ly/2Qdg7cm
[14] Buame. S. (2009). Entrepreneurial Education, Venture Creation and SME Management in Ghana. Accra: Big Mike's Publication Limited.

[15] Carr, S., \& Roulin, A. (2016). An Exploration of Agripreneurship Scope, Actors and Prospects. Retrieved from https://bit.ly/2zs X3zL

[16] Commonwealth Secretariat, (1998). The Commonwealth Plan of Action for Youth Empowerment 2007 - 2015. Retrieved from https://bit.ly/2qs Tzt5

[17] Cooke, E., Hague, S., \& McKay, A. (2016). The Ghana Poverty and Inequality Report. Retrieved from https://uni.cf/2FB69LH

[18] Davidsson. P. (2005). The Types and Contextual Fit of Entrepreneurial Processes. International Journal of Entrepreneurship Education, 2(4), pp. 407-430. Retrieved from https://bit.ly/2zswNpk

[19] De Clercq, M., Vats, A. \& Biel, A. (2018). Agriculture 4.0: The Future of Farming Technology (WGS Report). Retrieved from World Government Summit website: https://bit.ly/2oVpYrs

[20] Dewan, S., \& Peek, P. (2007). Beyond Employment/Unemployment Dichotomy. (ILO Working Paper No. 83). Retrieved from the International Labour Organization website: https://bit.ly/2Jt71FW

[21] de Wolf. P., \& Schoorlemmer. H. (2007). Exploring the Significance of Entrepreneurship in Agriculture. (Report of Research Institute of Organic Agriculture). Retrieved from Organic Eprints website: https://bit.ly/2qs78sC

[22] Drucker, F. P. (1985). Innovation and Entrepreneurship: Practice and Principles. Retrieved from https://bit.ly/2HGbnZ4

[23] Dyer, K. W. (2013). Young People and Agri-food: Aspirations, Opportunities and Challenges. (CAADP Policy Brief 09). Retrieved from UK Gov International aid and Development website: https://bit.ly/2qqIZCG

[24] EIU-BCFN, (2017). Fixing Food; Towards a More Sustainable Food System. (BCFN Report). Retrieved from Barilla Center for Food \& Nutrition website: https ://bit.ly/2PbH8R3

[25] FAO, (2018). Food and Agriculture Driving action across the 2030 Agenda for Sustainable Development. Retrieved from: https://bit.ly/2u $4 \mathrm{jx} 7 \mathrm{~h}$

[26] FAO, (2017). The future of Food and Agriculture; Trends and Challenges. Retrieved from: http://www.fao.org/3/a-i6583e.pdf

[27] FAO, (2015). Ghana-Country fact sheet on Food and Agriculture Policy Trends. Retrieved from https://bit.ly/2Dlksrp 
[28] Feighery, J., Ingram, P., Li, S. \& Redding , S. (2011). Intersections of Youth and Food Security. Retrieved from https://bit.ly/2ztq2DE

[29] Flink, I., Vaast, C., Jacobs, J., \& Turolla, M. (2018). Youth in Agricultural Cooperatives: Opportunities and Challenges. Retrieved from https://bit.ly/2zvWvt3

[30] Filmer, D., \& Fox, L. (2014). Youth Employment in Sub-Saharan Africa. (Report No: ACS8133). Retrieved from World Bank website: https://bit.ly/2zmmzWl

[31] Fick, M. (2015). Ageing cocoa farmers pose risk for Ghana industry. Retrieved from https://on.ft.com/2D9Jx8E on 1 November 2018

[32] Ghana Statistical Service, (2014a). Ghana Living Standards Survey Round 6 (GLSS6); Labour Force Report. (GSS Report). Retrieved from Ghana Statistical Service website: https://bit.ly/2O02FdX

[33] Ghana Statistical Service, (2014b). Ghana Living Standards Survey Round 6 (GLSS6); Poverty Profile in Ghana 2005-2013. (GSS Report). Retrieved from Ghana Statistical Service website: https://bit.ly/1S8LEti

[34] Goemans, C. (2014). Access to Knowledge, Information and Education. In Duffy. R (Ed), Youth and Agriculture: Key Challenges and Concrete Solutions. Retrieved from http://www.fao.org/3/ai3947e.pdf

[35] Herrington, M., \& Kelley, D. (2012). African Entrepreneurship - Sub-Saharan African Regional Report. (GEM Report). Retrieved from Global Entrepreneurship monitor website: https://bit.ly/2Pa9Rpj

[36] IFAD, (2018). IFAD'S Engagement with Rural Youth. Retrieved from https://bit.ly/2O9gmDH

[37] ILO, (2017). Global Employment Trends for Youth 2017: Paths to a better Working Future. Retrieved from: https://bit.ly/2nFvTjM

[38] Kahan, D. (2013). Entrepreneurship in Farming. Retrieved from https://bit.ly/2PEICmd.

[39] Kirzner, I. M. (2008). The Alert and Creative Entrepreneur: A Clarification. (IFN Working Paper No. 760). Retrieved from SSRN website: https://bit.ly/2OpWBI3

[40] Kunene, T., R. (2008). A Critical Analysis of Entrepreneurial and Business Skills in SMEs in the Textile and Clothing Industry in Johannesburg, South Africa. (Doctoral dissertation). Retrieved from https://bit.ly/2RCGAAt

[41] Koe. W-L. (2016). The relationship between Individual Entrepreneurial Orientation (IEO) and Entrepreneurial Intention. Journal of Global
Entrepreneurship Research, 6 (13). doi: 10.1186/s40497-016-0057-8.

[42] Lans, T., Bergevoet, R., Mulder, M., \& Van Woerkum, C. (2005). Identification and Measurement of Competences of Entrepreneurs in Agribusiness. In Batterink, M., R. Cijsouw, M., Ehrenhard, H., Moonen \& P. Terlouw (Eds.), Selected Papers from the 8th Ph.D. Conference on Business Economics, Management and Organization Science, PREBEM/NOBEM, Enschede. (pp. 81-95). Retrieved from https://bit.ly/2F7pMjF

[43] Leavy, J., \& Hossain, N. (2014). Who Wants to Farm? Youth Aspirations, Opportunities and Rising Food Prices. (IDS Working Paper Volume 2014 No 439). Retrieved from Wiley Online Library website: https://bit.ly/2F1W0gh

[44] Lewinsky, T., \& Muharemovic, A. (2011). CSO Management; Practical Tools for Organisational Development Analysis. Retrieved from: https://bit.ly/2F6uD4R

[45] Martin, R. L., \& Osberg, S. (2007). Social Entrepreneurship: The Case for Definition. Retrieved from https://bit.ly/2QrzbnD

[46] McElwee, G. (2015). Developing Entrepreneurial Skills of Farmers. Retrieved from: https://bit.ly/2OrOhHI

[47] Ministry of Employment and Labour Relations, (2014). National Employment Policy - Ghana. Retrieved from https://bit.ly/2qsc3d7

[48] Ministry of Youth and Sports, (2010). National Youth Policy of Ghana. Accra, Ghana: Ministry of Youth and Sports.

[49] Montpellier Panel, (2014). Small and Growing Entrepreneurship in African Agriculture. Retrieved from https://bit.ly/2yL61IY

[50] Moreane, P. (2016). A Study of Graduates' experience of Unemployment in Durban, South Africa. (Master's thesis). Retrieved from https://bit.ly/2F5iAo6

[51] Nassif, V. M. J., Ghobril, A. N., \& da Silva, N. S. (2010). Understanding the Entrepreneurial Process: A Dynamic Approach. Brazilian Administrative Review, 7:2(6), 213-226. Retrieved from https://bit.ly/2zs ARpA

[52] NDPC and UN Ghana, (2015). Ghana Millennium Development Goals 2015 Report. Retrieved from https://bit.ly/2OYBq4Z

[53] OECD, (2013). The OECD Action Plan for Youth Giving Youth a Better Start in The Labour Market. Retrieved from https://bit.ly/2ySqYll

[54] O'Leary, Z. (2004). The Essential Guide To Doing Research. London: Sage Publications. 
[55] Oppenheimer, J., \& Spicer, M. (2011). Putting Young Africans to Work; Addressing Africa's Youth Unemployment Crisis. (BF Discussion Paper 2011/08). Retrieved from Brenthurst Foundation website: https://bit.ly/2MYeHku

[56] Pahuja, A. (2015). Introduction to Entrepreneurship. Retrieved from https://bit.ly/2BYJOKS

[57] Phelan, C. (2014). Understanding the farmer: An analysis of the Entrepreneurial Competencies required for Diversification to Farm Tourism. (Doctoral dissertation). Retrieved from https://bit.ly/2Ot7au5

[58] Poerwowidagdo, J. S., \& Ghee, Y. W. (2011). Entrepreneurial Logistics: An Application of Timmons Model in the Mini Business Project for Undergraduate Business Students. Retrieved from https://bit.ly/2F2gqWv

[59] Pyburn, R., Audet-Bélanger, G., Dido, S., Quiroga, G., \& Flink, I. (2015). Unleashing Potential: Gender and Youth Inclusive Agri-food Chains. (KIT Working Paper 2015-7). Retrieved from SNV website: https://bit.ly/2SQBWA9

[60] Ratvi, H. (2013). Entrepreneurs' Personality Traits and their Success: An Empirical Analysis. Retrieved from https://bit.ly/2yTbldn

[61] Saxena, P. (2013). A Study of Entrepreneurial Traits through Organizational Leaders. International Journal of Management \& Business Studies. Retrieved from https://bit.ly/2RzrjAs

[62] Schoof. U., 2006. Stimulating Entrepreneurship: Barriers and Incentives to Enterprise Start-ups by Young People. Retrieved from: https://bit.ly/2yLdaJp

[63] Sumberg, J., Anyidoho, N. A., Leavy, J, te Lintelo J. L. D., \& Wellard, K. (2012). Introduction: The Young People and Agriculture "Problem" in Africa'. Retrieved from https://bit.ly/2PnRgpS

[64] UNESCO, [ca. 2018]. Ghana-Participation in Education; Tertiary Education. Retrieved from https://bit.ly/2JZb7WJ

[65] UN DESA, (2017). World Population Prospects 2017 Revision. [World population disaggregated by regions of the world and age group]. Retrieved fromhttps://population.un.org/wpp/DataQuery/ Accessed 20th October 2018

[66] UNDP, (2014). UNDP Youth Strategy 2014 - 2017. Retrieved from https://bit.ly/1BIN7pM

[67] UNIDO, (2013). Agribusiness DevelopmentTransforming Rural life to Create Wealth. Retrieved from https://bit.ly/2Oh9ZxT

[68] Van der Veen, M., \& Wakkee, AM. I. (2004). Understanding the Entrepreneurial Process. Retrieved from https://bit.ly/2OrPsab
[69] Verschuren , P., \& Doorewaard, H. (2010). Designing a Research Project. (2nd ed.). Hague, Netherlands: Eleven International Publishing.

[70] Weidinger, R., Youdeowei, A., University of Greenwich, Mwaura, G., \& Quaye, E. (2015). Agricultural Entrepreneurship: Transforming African Youth Livelihoods through Agribusiness Development. In Ameyaw, D. S. (Ed.) Africa Agriculture Status Report 2015; Youth in Agriculture in Sub-Saharan Africa (pp. 62-93). Retrieved from https://bit.ly/2OXC4uX

[71] Zamanian, M., 2017. Measuring Entrepreneurial Performance: Is There Consistency Between Scholars?. Retrieved from https://bit.ly/2yU7fSj 